\title{
MINERAL INDUSTRY OF ALASKA IN 1924
}

\section{By Philip S. Smith}

\section{INTRODUCTION}

This volume is the twenty-first of a series of annual bulletins ${ }^{1}$ summarizing the results achieved during the year in the investigation of the mineral resources of Alaska and treating of the mineral deposits and of the statistics of mineral production of the Territory. ${ }^{2}$ This volume, like those previously issued, has for its chief purpose the prompt publication of the more significant economic results of the year. The articles included are mainly statements of preliminary results and may be modified when the field material is more fully studied. Those who are interested in any particular problem or district are therefore urged to procure a copy of the coinplete report on it as soon as it is available.

The information included in this volume could not have been prepared without the data furnished by many residents of the Territory, some of whom have rendered this assistance for many years. However, many still fail to report their mining operations. To those who fail to report because of fear that their confidential data may be disclosed to competitors or others who might use the information to the sender's disadvantage the Survey would say that all schedules of production are regarded as confidential, are not open to inspection, and are not used in any form that would disclose the production of individuals. Even members of the Survey who are working in other parts of Alaska than those to which the specific reports relate do not have access to them. To those who refrain from reporting because of the small size of their production the Survey would say that the accuracy of its results depends upon having reliable data from every operator, even from those who have produced nothing during the current year. As the final figures are based in part on estimated production of all claims, if a claim produced nothing definite information of that fact may prevent an erroneous estimate.

The Survey appreciates the efforts made by prospectors and miners throughout the Territory in filling in and transmitting its schedules and would gladly avoid asking for unnecessary information or simplify its inquiries. It therefore welcomes constructive criticism as to how these desirable objects may be effected. In return, it aims to give the best statistical information that it can

1 The preceding volumes in this series are U. S. Geol. Survey Bulls. 259, 284, 314, 345, $379,442,480,520,542,592,622,642,662,692,712,714,722,739,755$, and 773 .

The statistics in this report have been compiled principally by Miss Erma C. Nichols. 
regarding the developments during the year in the mineral industry of Alaska. In the interest of increasing its value to the Alaska mining industry as a whole and to each operator individually the Geological Survey requests more complete and prompter return of its schedules by the Alaska mining operators. To be of service the Survey reports should be in the hands of the users at the earliest possible moment. Delays in returning the schedules mean delay in publication of the results, so that anyone who delays sending in his report not only causes additional expense but also decreases the value of the result.

It is impossible to record here the names of all who have rendered aid to the Geological Survey during the past year, as the list would include more than a thousand names.

Special acknowledgment should be made to the Territorial mine inspector and resident engineer of the Bureau of Mines, who furnished the data on coal production, as well as other valuable information; to N. L. Wimmler, also of the Bureau of Mines, for information about gold placers; to George Parks, now Governor of Alaska, and H. K. Carlisle, of the General Land Office; to the directors and other officers of the Bureau of Mines and Bureau of the Mint; to the collector and other officers of the Alaska customs service; to the officers of the Alaska Railroad; to Charles H. Flory, forest supervisor for Alaska; to John C. McBride and the Alaska Juneau Gold Mining Co., of Juneau; Thomas Vogel, of Haines; J. H. Cann, of Chichagof; Thomas G. White, of Katalla; the Kennecott Copper Corporation, of Kennicott; Thomas Larson, of Chitina ; J. M. Elmer, of Dempsey; S. W. Jensen and H. W. Nagley, of Talkeetna; Alex Liska and Sumner Smith, of Anchorage; Louis Huber, of Seldovia; Arthur Moose Johnson, of Chulitna; J. H. Lander, of Wasilla; Charles Zielke, of Nenana; Carl F. Whitham, of Chisana; A. W. Amero, of Beaver; J. J. Hillard, of Eagle; Alfred Johnson, of Deadwood; John C. Boyle and Frank Slaven, of Circle; the First National Bank, George Hutchinson, and G. E. Jennings, of Fairbanks; Charles E. M. Cole, of Jack Wade; J. H. Elden, of Steel Creek; the Miners \& Merchants Bank, of Iditarod; E. J. Stier, of Flat; Frank Speljack, of Ophir; George W. Huey, of Wiseman; Tom Plunkett, of Fortuna Ledge; J. W. Wick, of Russian Mission; B. J. Bower, of Long; Lynn Smith, of Ruby; A. Stecker and John Haroldsen, of Kwinak; the Miners \& Merchants Bank, A. W. Kah, and R. W. J. Reed, of Nome; E. M. Marx, of Teller; T. P. Roust, of Candle; A. S. Tucker, of Bluff; James C. Cross and Lewis Lloyd, of Shungnak; and J. J. Elliot, of Haycock.

\section{GENERAL FEATURES}

In presenting this annual inventory of the progress of mining in Alaska many facts are set forth which show that the Territory is really a treasure box and not the liability which some people, who do 
The decrease in silver is mainly a natural consequence of the decreased production of copper. The decrease in production of coal, about 20,000 tons, was due in large part to a serious fire in one of the largest mines. The decrease in both coal and silver is nearly offset by the increase in gold. On the whole, therefore, the decrease in 1924 may be considered as resulting from decreased production of copper. Further discussion of the details regarding the different metals and mineral products is given under each metal or material in later pages of this report.

The earlier volumes of this series contain complete tables of the production of all valuable metals for each year since they were first mined. With a view to reducing the size and cost of this volume many of these tables have been condensed, so that only the annual statistics for the last nine years are given and the production for the earlier years is grouped as one item. The reader interested in obtaining the more complete record should consult Bulletin 773.

Although complete tables have now been worked up for the annual production of gold, silver, copper, coal, tin, lead, placer platinum metals, and antimony, there are a number of mineral products, such as petroleum, gypsum, marble, and lode platinum metals that have not been so tabulated and either have not been determined or have been reported in the table on page 3 as miscellaneous mineral products. The following table has therefore been prepared, so that information as to the value of these miscellaneous mineral products should be readily available in one place.

Value of output of miscellaneous mineral products of Alaska, including petroleum, gypsum, marble, and other products, 1901-1924

\begin{tabular}{|c|c|c|c|c|c|}
\hline Year & Value & Year & Value & Year & Value \\
\hline \multirow{8}{*}{$\begin{array}{l}1901 \\
1902 \\
1903 \\
1904 \\
1906 \\
1907 \\
1908\end{array}$} & \multirow{8}{*}{$\begin{array}{r}\$ 500 \\
255 \\
389 \\
2,710 \\
710 \\
19,965 \\
54,512 \\
81,305 \\
86,027\end{array}$} & \multirow{8}{*}{$\begin{array}{l}1910 \\
1911 \\
1912 \\
1913 \\
1914 \\
1916 \\
1917 \\
1918\end{array}$} & \multirow{8}{*}{$\begin{array}{l}\$ 96,408 \\
145,739 \\
165,342 \\
286,277 \\
199,767 \\
205,061 \\
326,737 \\
203,971 \\
171,452\end{array}$} & \multirow{8}{*}{$\begin{array}{l}1919 \\
1920 \\
1921 \\
1922 \\
1924\end{array}$} & \multirow{6}{*}{$\begin{array}{r}\$ 214,040 \\
372,599 \\
235,438 \\
266,296 \\
229,486 \\
348,728\end{array}$} \\
\hline & & & & & \\
\hline & & & & & \\
\hline & & & & & \\
\hline & & & & & \\
\hline & & & & & \\
\hline & & & & & $3,713,713$ \\
\hline & & & & & \\
\hline
\end{tabular}

GOLD

TOTAL PRODUCTION

For many years gold was practically the only metal that was produced in any quantity in Alaska, and even now the value of the total production of gold far exceeds that of any other mineral. The following table gives the total annual production of gold for the last nine years and the gross output from 1880 to 1915. This table 
shows that altogether nearly $\$ 350,000,000$ worth of gold has been recovered since gold mining first began in the Territory in 1880 . As indicated in this table, the amount of gold produced in 1924 was about $\$ 300,000$ greater than in 1923 , and furthermore most of the increase came from the lode mines rather than from the placers. Additional information is given regarding the different types of deposits from which gold was produced and the different areas from which it came.

Gold and silver produced in Alaska, 1880-1924

\begin{tabular}{|c|c|c|c|c|c|c|}
\hline \multirow{2}{*}{ Year } & \multicolumn{2}{|c|}{ Gold } & \multicolumn{2}{|c|}{ Silver } & \multicolumn{2}{|c|}{ Value of gold by sources } \\
\hline & Fine ounces & Value & Fine ounces & $\underset{\text { value }}{\text { Commercial }}$ & Placer mines & Lode mines \\
\hline \multirow[t]{2}{*}{$\begin{array}{l}1880-1915 \\
1916 \\
1917 \\
1918 \\
1919 \\
1920 \\
1921 \\
1923 \\
1924\end{array}$} & $\begin{array}{r}12,592,121 \\
834,068 \\
709,049 \\
458,641 \\
455,984 \\
404,683 \\
390,558 \\
359,057 \\
229,539 \\
304,072\end{array}$ & $\begin{array}{r}\$ 260,302,243 \\
17,241,713 \\
14,657,353 \\
9,480,952 \\
9,426,032 \\
8,365,560 \\
8,073,540 \\
7,422,367 \\
5,985,314 \\
6,285,724\end{array}$ & $\begin{array}{r}4,923,198 \\
1,379,171 \\
1,239,150 \\
847,789 \\
629,708 \\
953,546 \\
761,085 \\
729,945 \\
814,649 \\
669,641\end{array}$ & $\begin{array}{r}\$ 2,821,911 \\
907,495 \\
1,021,060 \\
847,789 \\
705,273 \\
1,039,364 \\
761,085 \\
729,945 \\
668,012 \\
448,659\end{array}$ & $\begin{array}{r}185,200,444 \\
11,140,000 \\
9,810,000 \\
5,900,000 \\
4,970,000 \\
3,873,000 \\
4,226,000 \\
4,395,000 \\
3,608,500 \\
3,564,000\end{array}$ & $\begin{array}{r}\$ 75,101,799 \\
6,101,713 \\
4,847,353 \\
3,580,952 \\
4,456,032 \\
4,492,560 \\
3,847,540 \\
3,027,367 \\
2,376,814 \\
2,721,724\end{array}$ \\
\hline & $16,797,772$ & $347,240,798$ & $12,947,882$ & $9,950,593$ & $236,686,944$ & $110,553,854$ \\
\hline
\end{tabular}

Gold and silver produced in Alaska, 1924, by sources

\begin{tabular}{|c|c|c|c|c|}
\hline \multirow{2}{*}{ Bource } & \multicolumn{2}{|c|}{ Gold } & \multicolumn{2}{|c|}{ Silver } \\
\hline & Fine ounces & Value & Fine ounces & Value \\
\hline \multirow[t]{2}{*}{$\begin{array}{l}\text { Gold ores }(3,127,905 \text { short tons) } \\
\text { Copper ores }(761,779 \text { short tons) } \\
\text { Placers... }\end{array}$} & $\begin{array}{r}131,018.01 \\
645.37 \\
172,408.50\end{array}$ & $\begin{array}{r}\$ 2,708,383 \\
13,341 \\
3,564,000\end{array}$ & $\begin{array}{r}75,284 \\
572,078 \\
22,279\end{array}$ & $\begin{array}{r}\$ 50,440 \\
383,292 \\
14,927\end{array}$ \\
\hline & $304,071.88$ & $6,285,724$ & 669,641 & 448,650 \\
\hline
\end{tabular}

GOLD LODES

The production from the gold lodes amounted in 1924 to more than 17,500 ounces of fine gold, having a value of about $\$ 360,000$ above that in 1923. No new mines became notable producers during the year, and only a few mines that were producers in 1923 discontinued production in 1924. Nineteen mines which are here classed as gold mines because gold is the dominant metal in their ores and whose production was valued at more than $\$ 1,000$ during the year, reported production in 1924, the same number that reported in 1923. All lode properties that produced less than $\$ 1,000$ during the year are regarded as prospects.

The accompanying table gives information regarding the gold and silver produced from the gold mines in Alaska in 1924, by districts. 
Gold and sitver produced from gold-lode mines in Alaska in 1924, by districts

\begin{tabular}{|c|c|c|c|c|c|c|}
\hline \multirow{2}{*}{ District } & \multirow{2}{*}{$\begin{array}{l}\text { Num- } \\
\text { ber of } \\
\text { mines }\end{array}$} & \multirow{2}{*}{$\begin{array}{l}\text { Ore mined } \\
\text { (short tons) }\end{array}$} & \multicolumn{2}{|c|}{ Gold } & \multicolumn{2}{|c|}{ Silver } \\
\hline & & & Fine ounces & Value & Fine ounces & Value \\
\hline \multirow[t]{2}{*}{$\begin{array}{l}\text { Southeastern Alaska } \\
\text { Willow Creek } \\
\text { Fairbanks district. } \\
\text { Other districts } . . .\end{array}$} & $\begin{array}{l}6 \\
4 \\
5 \\
4\end{array}$ & $\begin{array}{r}3,112,507 \\
8,075 \\
4,528 \\
-2,795\end{array}$ & $\begin{array}{r}111,035.43 \\
9,765.83 \\
4,870.05 \\
5,346.70\end{array}$ & $\begin{array}{r}\$ 2,295,306 \\
201,878 \\
100,673 \\
110,526\end{array}$ & $\begin{array}{r}68,911 \\
754 \\
1,295 \\
4,324\end{array}$ & $\begin{array}{r}\$ 46,170 \\
505 \\
868 \\
2,897\end{array}$ \\
\hline & 19 & $3,127,905$ & $131,018.01$ & $2,708,383$ & 75,284 & 50,440 \\
\hline
\end{tabular}

- Including small amounts of galena ore.

The mines of southeastern Alaska continued to yield the greatest amount of gold, and of these the mine of the Alaska Juneau Gold Mining Co. was by far the largest producer. The record of this company is shown by the report of its operations which it publishes each year. The following table, taken from that report, shows the recovery of gold as well as the other metals from this mine: ${ }^{3}$

Production of Alaska Juneau mine, 1893-192, a

\begin{tabular}{|c|c|c|c|c|c|c|c|}
\hline \multirow[b]{2}{*}{ Year } & \multicolumn{3}{|c|}{ Ore (tons) } & \multicolumn{4}{|c|}{ Metals recovered } \\
\hline & Total & $\begin{array}{l}\text { Fine } \\
\text { milled }\end{array}$ & $\begin{array}{c}\text { Coarse } \\
\text { tailings } \\
\text { rejected }\end{array}$ & Gold & $\begin{array}{c}\text { Silver } \\
\text { (ounces) }\end{array}$ & $\underset{\text { (pounds) }}{\text { Lead }}$ & Total value \\
\hline \multirow[t]{2}{*}{$\begin{array}{l}1893-1913 \\
1914-1915 \\
1916 \\
1917 \\
1918 \\
1919 \\
1920 \\
1921 \\
1923 \\
1924\end{array}$} & $\begin{array}{r}507,254 \\
242,328 \\
180,113 \\
677,410 \\
592,218 \\
692,895 \\
942,870 \\
1,613,600 \\
2,310,550 \\
2,476,240 \\
3,068,190\end{array}$ & $\begin{array}{r}330,278 \\
239,918 \\
180,113 \\
677,410 \\
574,285 \\
616,302 \\
637,321 \\
904,323 \\
1,108,559 \\
1,134,759 \\
1,367,528\end{array}$ & \begin{tabular}{r}
176,976 \\
2,410 \\
\hdashline 17,933 \\
76,593 \\
305,549 \\
709,277 \\
$1,201,991$ \\
$1,341,481$ \\
$1,700,662$
\end{tabular} & $\begin{array}{r}\$ 707,730 \\
251,655 \\
115,022 \\
429,262 \\
430,124 \\
499,002 \\
732,870 \\
969,703 \\
1,296,157 \\
1,427,199 \\
1,907,374\end{array}$ & $\begin{array}{c}\text { Lost in } \\
6,192 \\
2,844 \\
12,248 \\
11,828 \\
16,431 \\
23,348 \\
40,619 \\
49,404 \\
41,876 \\
63,191\end{array}$ & \begin{tabular}{|r} 
tailings \\
117,031 \\
61,068 \\
296,179 \\
273,297 \\
359,762 \\
487,574 \\
550,913 \\
687,315 \\
755,423 \\
$1,256,857$
\end{tabular} & $\begin{array}{r}\$ 707,730 \\
261,326 \\
121,379 \\
460,666 \\
459,445 \\
542,714 \\
791,390 \\
1,035,251 \\
1,388,679 \\
1,514,774 \\
2,055,782\end{array}$ \\
\hline & $13,303,668$ & $7,770,796$ & $5,532,872$ & $8,766,098$ & 267,981 & $4,845,419$ & $9,339,136$ \\
\hline
\end{tabular}

a Compiled from published reports of mining company.

Some slight discrepancies between the figures in this table and those used by the Geological Survey are due principally to the fact that the price of some of the metals used by the Geological Survey in preparing its estimates is based on the average price for the year rather than on the actual price received by the producers. For instance, the price of lead, as computed from the figures given in the company's report, was 8.42 cents, whereas the price used by the Survey is 8 cents a pound. These differences are usually small, but in the example just cited the value of the lead given in the company's report is greater than the value of the whole production of lead in Alaska as given in the table on page 22, which was computed by the Survey. The report of this company further shows

slaska Juneau Gold Mining Co., Tenth Ann. Rept., for 1924, published Mar. 3, 1925 . 
that operations were carried on for 362 days during the year, that its mining and milling plants, which had an average capacity of 7,430 tons a day at the beginning of the year, had been increased at the end of the year to 9,520 tons a day, and that the average number of tons mined per day for the entire year was 8,476.

The Alaska Juneau Gold Mining Co. also continued throughout the year its development of the Ebner mine, which lies adjacent to its property. In the report of the company for 1923 Bradley said: ${ }^{4}$

Litigation over the boundary line between the Alaska Juneau property and the westerly adjoining Ebner property has been settled by an agreement that resulted in our taking possession of the entire Ebner property, which possession is to continue after November 2, 1925, either as long as we mill an average of a thousand tons per day from the westerly side of an agreedupon line between the Alaska Juneau and Ebner properties and equally divide the net profits, or as long as we employ a minimum of five men preparing the Ebner mine for profitably producing a thousand tons per clay.

Good headway is being made on the preparatory work, and the management expected that by November, 1925, a thousand tons of ore a day. would be coming from the Ebner mine.

Prospecting and development work on gold lodes was carried on in many of the other parts of the Juneau district. On Admiralty Island, in this district, a belt of metamorphic rocks, which extends from Funter Bay to Hawk Inlet, contains a great number of large well-defined quartz fissure veins with shoots carrying gold values. Several of these veins are being prospected on the properties of the Admiralty-Alaska Gold Mining Co. and the Alaska Dano Co. on Funter Bay and by Charles Williams and others on Hawk Inlet. A description of these properties by Buddington is given in another paper in this bulletin.

Work at the mines of the Chichagof Development Co., the HirstChichagof Mining Co., and the Apex El Nido Mining Co., all on Chichagof Island in the Sitka district, was continued actively throughout the year, and the mines report a considerable production of gold. A new mill was put in operation during the year at the Apex-El Nido property. The success of these mines has stimulated interest in prospecting for gold lodes in this region, and doubtless this search for new ore bodies will be in some places successful.

The only other mine in southeastern Alaska in which a gold lode was productively mined during 1924 was in the Ketchikan district, where the Kassan, Gold Mining Co. reports renewed mining at the Julia mine, near Hollis, throughout part of the year.

In the Copper River district the only mine which has been classed with the gold-lode mines was that of the North Midas Copper Co.,

« Bradley, F. W., Alaska Juneau Gold Mining Co. Ninth Ann. Rept, for 1923, published Mar. 11, 1924. 
in the Chitina region near Strelna. This mine, although placing emphasis on copper in its name, has been considered a gold lode because the most valuable part of its production is gold.

Very little gold-lode mining was carried on in the Prince William Sound region. The largest production came from the old RamseyRutherford mine, on the east side of Valdez Glacier, but some production was reported from the Tuscarora mine near Shoup Bay. Toward the end of the summer preparations were under way for further prospecting on the Little Giant claim on Mineral Creek, in the Valdez district. A number of men were engaged and a compressor installed to reopen the Cliff mine, near Shoup Bay.

Mining in the Kenai district was continued at the Lucky Strike mine of the Alaska Minerals Co., formerly the Hirshey mine, at the head of Palmer Creek near Hope. Further discoveries of goldquartz lodes at Nuka Bay, on the south shore of Kenai Peninsula, indicate that this may be the center of a large area of mineralization. According to report, a mill was to be installed there during 1924, and several of the veins are said to show promising indications. The Alaska Hills Mines Corporation, near Seward, also reported the recovery of some gold from its lode claim known as the Paystreak.

No important new developments are reported from the Willow Creek region during the year. The largest gold-lode production came from the War Baby claim of the Willow Creek mines, on Craigie Creek. None of the other mines of this company were in operation. The Fern Gold Mining Co.'s property, near the head of Archangel Creek, showed a considerable increase in production owing to the discovery of a rich shoot of ore. The Mabel, on the ridge west of the lower part of Archangel Creek, was operated for part of the season. The only other mine in the district that reported having recovered any lode gold during the year is that of Elder \& Thorpe, in the schist area near the mouth of Grubstake Gulch.

The Fairbanks district showed probably the greatest rate of increase in 1924 over 1923 of all Alaskan camps in its production of lode gold, for its output of gold in 1924 was more than $\$ 100,000$, as compared with an output of less than $\$ 25,000$ in 1923 . The largest amount of work was in the general neighborhood of Ester. Dome, especially near the head of St. Patrick Creek. Here Tyndall, Henderson, and McLoughlin, on the Mohawk claim, have taken out a considerable quantity of excellent ore. They have the only mill that is operating in the region. Most of the metal that is recovered is in the form of free gold. Sulphides, especially stibnite, and some galena and blende are fairly abundant in the ore, but no attempt is made to recover the gold intimately associated with them. The only other claim on Ester Dome which is reported to have milled any 
gold ore is the First Chance, operated by Sam Stay \& Co. Some development work was done on other claims in the neighborhood, but many of the owners have been "marking time," as negotiations are reported to have been in progress for a large consolidation of properties and their operation by companies not now active in the district. Lode prospecting in the vicinity of Fairbanks Creek has received a new impetus, and the Crites \& Feldman Hi $\mathrm{Yu}$ mine still continues to be a consistent producer. The old Rhoads-Hall mine, on Bedrock Creek, a tributary of Cleary Creek, operated by Gustafson Bros., and the Wyoming claim, on the same stream, both produced some gold. Much of the work done at the Gustafson mine, however, was "dead" work required in reopening the mine, which had stood idle for several years, and in developing an adequate new systematic plan for mining the deposit.

The only productive lode-gold mining in the Kuskokwim basin was at the Whelan mine, in the Nixon Fork country. This general region was visited by a Survey party in 1924, and the geology and economic facts regarding it are described in considerable detail by J. S. Brown in another chapter of this bulletin. The gold recovered this year was mined during the winter of 1923-24 and was milled in the 20-stamp mill owned by the Alaska Treadwell Gold Mining Co., which had been leased to an association that included the owners of the Whelan mine. This mill was operated for 73 shifts, after which the mine and mill were practically closed down, though further prospecting in the neighborhood was undertaken.

In addition to the lode gold won from the lode mines discussed in the preceding pages, considerable gold was also recovered from the mines classed as copper lodes, which are described on pages 20-22. The gold recovered from the copper lodes amounts to 645.37 ounces of fine gold, valued at $\$ 13,341$.

\section{GOLD PLACERS}

\section{GENERAL FEATURES}

Gold placers are widely distributed through Alaska. Because in the early stages of their development many placers can be mined with relatively little heavy equipment and because the resulting product is small in bulk and high in value in comparison with its weight, they can be mined profitably in rather inaccessible regions where transportation facilities are poor. Even in the most remote parts of the Territory some gold still comes from placers. The cost of operating deposits by hand labor is, however, relatively high, and a decrease in cost can be effected only by the installation of 
suitable machinery or the leading to the properties of large volumes of water under control. Most of the developed camps have reached the stage where the known rich bonanzas have been worked out and successful operation requires good mining practice and considerable labor-saving machinery. A person now undertaking placer mining must therefore either be prepared to go into the more inaccessible parts of the Territory or have sufficient capital to provide rather extensive equipment and to buy up claims staked by others. In other words, placer mining in Alaska is fast ceasing, if it has not already ceased, to be a business in which poor men inexperienced in mining can quickly become wealthy. It is still, however, a kind of work in which a person without much money can probably make as comfortable a living as can be made in the States with perhaps no more work and with the added attraction and disadvantage that the prospector is his own boss.

The total production of placer gold, distributed according to the districts in which it is produced, is shown in the following table:

Statistics of placer mining in Alaska in 1923 and 1924

\begin{tabular}{|c|c|c|c|c|c|}
\hline \multirow[b]{2}{*}{ Region } & \multicolumn{2}{|c|}{$\underset{\text { mines }}{\text { Number of }}$} & \multicolumn{3}{|c|}{ Value of gold produced } \\
\hline & 1923 & 1924 & 1923 & 1924 & $\begin{array}{c}\text { Decrease } \\
\text { or } \\
\text { increase, } \\
1924\end{array}$ \\
\hline 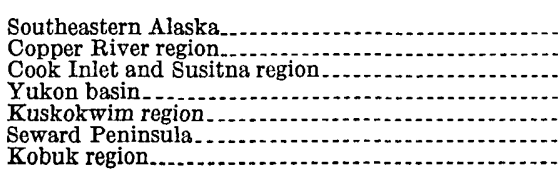 & $\begin{array}{r}5 \\
12 \\
35 \\
365 \\
30 \\
66 \\
8\end{array}$ & $\begin{array}{r}4 \\
9 \\
39 \\
374 \\
25 \\
84 \\
5\end{array}$ & $\begin{array}{r}\$ 3,500 \\
144,000 \\
247,000 \\
1,644,000 \\
292,000 \\
1,270,000 \\
8,000\end{array}$ & $\begin{array}{r}\$ 7,000 \\
130,000 \\
168,800 \\
1,740,500 \\
268,700 \\
1,245,000 \\
4,000\end{array}$ & $\begin{array}{r}+\$ 3,500 \\
-14,000 \\
-78,200 \\
+96,500 \\
-23,300 \\
-25,000 \\
-4,000\end{array}$ \\
\hline & 521 & 540 & $3,608,500$ & $3,564,000$ & $-44,500$ \\
\hline
\end{tabular}

In addition to the gold and silver some platinum and tin ore (cassiterite) are recovered in the course of placer mining.

The foregoing table shows that the production of gold from the placer mines in 1924 was almost identical with the amount produced from the same source in 1923. This correctly indicates the actual condition, that placer mining in the two years was done on practically the same scale and that there were no new strikes that affected the production to a marked degree, nor did any of the large formerly productive camps show decided increase in output. Although not yet reflected in their effect on production, several important events that took place during the year before long should stimulate placer mining, especially in the Fairbanks and Nome districts. One of 
these events was the announcement, in August, that the Hammon Consolidated Gold Fields and the United States Smelting \& Refining Co. had effected a consolidation of certain of their Alaskan holdings under the joint ownership of a company known as the Fairbanks Exploration Co. This consolidation had been in effect only a few months when, in the spring of 1925 , the announcement was made that the United States Smelting \& Refining Co. had taken over all the holdings of the Hammon corporation in Alaska, including the dredges at Nome as well as the many claims in the Fairbanks district. It is still too early to predict what developments will be undertaken in the near future, but the well-known success of the company in carrying through vigorously any work it undertakes gives every assurance that the properties will be brought to a producing stage as early as the most expert mining methods will permit. Not only will this enterprise have a direct effect on the mining industry of the Territory but it will be of indirect benefit in educating new miners in Alaskan methods and will afford work for many who will use some of the wages they earn as stakes to do some prospecting on their own account.

Another consolidation of claims, many of which have lain idle for several years, was effected by a company supposed to represent mainly English capital. The main area in which this company has acquired ground is in the vicinity of Engineer Creek, in the Fairbanks district. This arrangement was made late in the year, and the plan of development has not yet been announced. Carefully managed mining in this region on a large scale, backed by adequate funds, should give attractive returns on the investment and be of benefit not only to the producing company but also to the mining industry as a whole and to all the activities of the district tributary to the area in which the work is done.

An interesting experiment that is being tried in one of the drift mines on Little Eldorado Creek in the Fairbanks district is the mining of frozen ground by blasting rather than by thawing it with steam or water. According to J. S. Brown, this experiment was tried at the mine of the Idaho Mining \& Leasing Co. At this property the shaft is about 175 feet deep and from it about 800 feet of drifts have been driven. The mining practice here is to use a general long-wall system of undercutting by blasting the frozen gravels, taking out 3 to 4 feet of the gravels and 2 to 3 feet of the upper bedrock. The frozen gravel is said to stand well without thawing, but the material broken by blasting that contains the gold thaws rapidly when exposed to the air for a short time, and its subsequent treatment for the recovery of the gold is the same as that for 
other thawed material. If this system proves practicable it should have considerable application in many of the deep placers both of Seward Peninsula and of the interior of Alaska.

\section{NOTES ON THE PLACERS BY REGIONS}

Southeastern Alaska.-The only places in southeastern Alaska in which placer mines were worked in 1924 were the Juneau region, the Porcupine district, and the Yakataga district. In none of these places, however, were more than two claims worked and at none was more than a few thousand dollars in gold produced. All the gold came from stream placers except from two in the Yakataga district, where marine beach sands were mined. The total production for all of southeastern Alaska is shown in the table on page 10.

Copper River region.-Three districts in the Copper River region reported some production of placer gold. In the order of their output these were the Nizina, Chistochina, and Nelchina districts. A good-sized mine on Chititu Creek and another on Dan Creek and two small ones, one each on $\operatorname{Rex}$ and Dan creeks, were the only mines that were in operation in the Nizina district. With the exception of the Slate Creek Mining Co.'s work on Slate Creek, all the placer mines in the Chistochina and Nelchina districts were very small. There was only one other placer mine in the Slate Creek district and three in the Nelchina. The production of placer gold for all of the Copper River region is given in the table on page 10.

Cook Inlet-Susitna Basin.-The Yentna was by far the most productive district in the Cook Inlet-Susitna Basin region. Here 23 different mines, including one dredge, produced placer gold worth $\$ 136,900$. Most of the mines produced only a few thousand dollars in gold and only a few produced more than $\$ 10,000$.

In the Kenai district the placer production, which was $\$ 27,900$, came from 10 mines, most of them, except the claims on Crow Creek, producing less than $\$ 5,000$ each in gold and some of them only a few hundred dollars. These small producers were located on Canyon, Bear, Lynx, Mills, Resurrection, and Sixmile creeks, and on Resurrection River and Nuka Bay.

In the Valdez Creek district four claims, three of which were on Lucky Gulch and one on White Creek, mined a little placer gold.

Yulcon basin.-The scope of placer mining in the Yukon basin is summarized briefly in the following table, which affords a ready comparison between the placer production in 1924 and in 1923. As shown in the table, there was an increase in 1924 over 1923 of about $\$ 100,000$, a large part of which might be attributed to the increased production in the Fairbanks district. 
Placer gold produced in Yukon basin, 1923 and 1924, by districts

\begin{tabular}{|c|c|c|c|c|}
\hline \multirow{2}{*}{ District } & \multicolumn{2}{|c|}{ Value of gold } & \multicolumn{2}{|c|}{ Number of } \\
\hline & 1923 & 1924 & 1923 & 1024 \\
\hline $\begin{array}{l}\text { Fairbanks and Richardson } \\
\text { Iditarod. } \\
\text { Tolovana } \\
\text { Innoko (including Tolstoi district) } \\
\text { Circle } \\
\text { Ruby } \\
\text { Hot Springs } \\
\text { Fortymile. } \\
\text { Chandalar } \\
\text { Koyukuk (including Indian } \mathrm{River} \text { district) } \\
\text { Chisana } \\
\text { Eagle } \\
\text { Rampart (including Gold } \text { Bili district) } \\
\text { Bonnifeld } \\
\text { Kantishna } \\
\text { Marshall }\end{array}$ & $\begin{array}{r}\$ 619,000 \\
228,000 \\
164,000 \\
153,000 \\
114,000 \\
72,000 \\
62,000 \\
53,000 \\
42,000 \\
37,000 \\
23,000 \\
23,000 \\
16,000 \\
13,000 \\
13,000 \\
12,000\end{array}$ & $\begin{array}{r}\$ 680,400 \\
207,100 \\
189,500 \\
161,200 \\
90,200 \\
84,600 \\
83,400 \\
31,800 \\
17,900 \\
54,000 \\
23,400 \\
49,800 \\
16,000 \\
12,500 \\
18,800 \\
19,800\end{array}$ & $\begin{array}{r}88 \\
20 \\
26 \\
23 \\
24 \\
32 \\
18 \\
42 \\
6 \\
20 \\
9 \\
11 \\
8 \\
13 \\
13 \\
12\end{array}$ & $\begin{array}{r}74 \\
21 \\
.20 \\
19 \\
26 \\
32 \\
22 \\
51 \\
6 \\
27 \\
8 \\
19 \\
8 \\
13 \\
18 \\
10\end{array}$ \\
\hline & $1,644,000$ & $1,740,500$ & 365 & 374 \\
\hline
\end{tabular}

It is rather surprising that most of the camps that made the greatest production showed so little change in the two years. In fact, the order of the first seven districts, based on production of placer gold, showed no change. A considerable amount of the placer gold from the Yukon region is recovered by dredges. A large amount of drift mining is done, especially in the Fairbanks, Tolovana, Fortymile, and Koyukuk districts. Many of the districts in the Yukon basin are now so close to relatively good transportation facilities that the more prosperous ones have rather extensive equipment. Some of the camps, however, are difficult of access, and further road building and trail making should unquestionably be undertaken, as this work would undoubtedly stimulate production and lead to the development of new deposits.

As already noted, the Fairbanks district, with which the Richardson district has been included in the table given below, produced the most placer gold. The table shows the amount of placer gold produced by camps on the different streams in the Fairbanks district for 1923 and 1924 and from the beginning of mining on the different streams, the first gold having been taken from the district in 1903.

Gold production by streams in Fairbanks district

\begin{tabular}{|c|c|c|c|}
\hline & 1023 & 1924 & $\begin{array}{l}\text { Approxi- } \\
\text { mate total } \\
\text { to date }\end{array}$ \\
\hline \multirow[t]{2}{*}{$\begin{array}{l}\text { Cleary Creek and tributaries } \\
\text { Goldstream Creek and tributaries } \\
\text { Ester and adjacent creeks } \\
\text { Dome and Fairbanks creeks. } \\
\text { Vault Creek and tributaries. } \\
\text { Little Eldorado Creek } \\
\text { All other creeks. }\end{array}$} & $\begin{array}{r}\$ 54,000 \\
201,000 \\
54,000 \\
225,000 \\
32,000 \\
20,000 \\
17,000\end{array}$ & $\begin{array}{r}\$ 97,600 \\
226,000 \\
102,600 \\
181,500 \\
15,900 \\
33,900 \\
22,900\end{array}$ & $\begin{array}{r}\$ 23,349,800 \\
15,512,000 \\
11,600,000 \\
16,892,100 \\
2,749,000 \\
2,414,000 \\
740,000\end{array}$ \\
\hline & 603,000 & 680.400 & $73,257,000$ \\
\hline
\end{tabular}


In the Iditarod district two dredges and the Chicken Creek Mining Co. on Chicken Creek and the Alpha Mining Co. on Flat Creek were the largest of the 21 mines that were operated in 1924. None of the others produced as much as $\$ 10,000$ in gold. Other creeks in this district that yielded placer gold were Granite, Happy, Cripple, and Willow creeks., Mining in the Tolovana district.was reported by several mines on Livengood, Lillian, Amy, Ruth, and Willow creeks, named in the order of decreasing production of gold. Of the 20 producers in this district 6 produced at least $\$ 10,000$ in gold. Outside of three dredges-two on Ganes and one on Yankee Creek-the production of placer gold in the Innoko district came from 16 mines, the largest of which produced less than $\$ 20,000$. More than 26 placer mines were in operation in the Circle district, and all of them except the dredge on Mastodon Creek were relatively small operations, none of which produced as much as $\$ 10,000$ in gold.

None of the mines in the Ruby district produced more than a few thousand dollars in gold in 1924. In the Tolstoi district, which has been tabulated with the Innoko district, the production was almost negligible. An increase in production was reported by the Hot Springs district, especially from American Creek and Sullivan Creek and its tributaries in the western part of the district, and Omega and Eureka creeks and tributaries in the eastern part of the district. More than 50 placer mines were active in the Fortymile district. The greatest production came from Jack Wade Creek and its tributaries, Chicken Creek, and Fortymile River proper, but with fer exceptions most of the claims individually produced only a few hundred dollars worth of gold.

In the Chandalar district the placer gold came mainly from Big Creek and from Big Squaw and Little Squaw creeks. The placer mines on the Koyukulk report an increased production over 1923. Most of the 27 properties that were mined, however, produced only a few thousand dollars worth of gold each. The most productive placer mining in the Chisana district was on Bonanza and Little Eldorado creeks, and about the same amount of gold was produced as in 1923. In the Eagle district the production of placer gold came from Seventymile River and its tributaries, especially Alder, Crooked, and Fox creeks, from Fourth-of-July Creek, and from American Creek and its tributaries, especially Discovery Fork. On Hunter Creek and Little Minook Creek were the most productive placer camps in the Rampart district. Most of the mines were small, and each produced only a few thousand dollars worth of gold. The report of the Richardson district has been tabulated with that of the Fairbanks district, as there are only two operating 
mines in it. The largest of these mines is that of the Salcha Mining Co. on Caribou Creek, a tributary of Salcha River, and the other is on Democrat Creek.

In the Bonnifield district placer gold was produced by 13 small mines, none of which recovered more than a few thousand dollars worth of gold. In the Kantishna district also the placer gold was mined by a number of small plants, many of which recovered only a few hundred dollars worth of gold and the largest only a few thousand dollars.

Information from different sources regarding mining in the Marshall district is not in entire accord. Apparently in 1924 the greatest production came from Flat, Willow, Buster, Disappointment, and Montezuma creeks.

Kuskokwim basin.-The placer gold produced in the Kuskokwim basin came from the Mount McKinley, Georgetown, TuluksakAniak, and Goodnews districts. The greatest production in the Mount McKinley district, in fact in the entire Kuskokwim basin, was made by the Kuskokwim Dredging Co.'s dredge on Candle Creek. The largest of the other placer camps in this district were on Moore, Hidden, and Holmes creeks, with several small producers on other creeks near McGrath. Notes on the economic geology of the Nixon Fork country, including a description of some of the areas that have been prospected or worked for gold placers, are given in a report by J.S. Brown that forms another chapter of this bulletin.

In the Georgetown district some placer mining was done at two properties on Donlin Creek. In the Tuluksak-Aniak district, 10 placer mines produced some gold. The largest amount of mining was done on Canyon and Bear creeks, but even the largest producers recovered only a few thousand dollars in gold. Four small mines were worked in the Goodnews district. With the exception of the property on Watermuse Creek only a little gold was produced by each of the other operators.

Seward Peninsula.-Placer mining in Seward Peninsula was done on essentially the same scale as that maintained during the past two or three years, and about the same production was made. As heretofore, the dredges contributed the most gold, but the amount was somewhat less than that produced in the preceding year. The decrease was due in part to the discontinuance of some of the older dredges and to the fact that some of the newer ones were in operation only a part of the season. The following table gives a comparison between the amounts of gold won by different methods of mining in Seward Peninsula in 1923 and in 1924.

$78644^{\circ}-26-2$ 
Placer gold produced in Seward Peninsula in 1923 and 1924, by methods of mining

\begin{tabular}{|c|c|c|c|c|}
\hline \multirow{2}{*}{ Method } & \multicolumn{2}{|c|}{$\begin{array}{c}\text { Number of } \\
\text { mines }\end{array}$} & \multicolumn{2}{|c|}{ Value of gold } \\
\hline & 1923 & 1924 & 1923 & 1924 \\
\hline \multirow[t]{2}{*}{$\begin{array}{l}\text { Dredging } \\
\text { Drifting } \\
\text { Other methods of mining }\end{array}$} & $\begin{array}{l}16 \\
10 \\
40\end{array}$ & $\begin{array}{r}16 \\
7 \\
61\end{array}$ & $\begin{array}{r}\$ 1,017,620 \\
51,290 \\
201,090\end{array}$ & $\begin{array}{r}\$ 896,210 \\
38,700 \\
310,090\end{array}$ \\
\hline & 66 & 84 & $1,270,000$ & $1,245,000$ \\
\hline
\end{tabular}

The great increase in the number of mines worked by methods other than drifting and dredging is in part real but in part due to the inclusion of a number of prospects, some of which produced at most only a few hundred dollars' worth of gold and were not included in the records for 1923, though the gold they produced was included in the total production of that year. Practically all the increase in production by methods of mining other than dredging and drifting came from the Nome region. In the following table the placer gold produced in Seward Peninsula in 1923 and 1924 is distributed by districts, so far as possible without disclosing the production of individual mines. This table indicates that the Nome district made a very large increase in production, whereas the Solomon, Casadepaga, and Council districts, which have been grouped together, showed the greatest decrease.

Placer gold produced in Seward Peninsula, 1923 and 1924, by districts

\begin{tabular}{|c|c|c|c|c|}
\hline \multirow{2}{*}{ District } & \multicolumn{2}{|c|}{$\begin{array}{c}\text { Number of } \\
\text { mines }\end{array}$} & \multicolumn{2}{|c|}{ Value of gold } \\
\hline & 1923 & 1924 & 1923 & 1924 \\
\hline $\begin{array}{l}\text { Nome } \\
\text { Solomon, Casadepaga, and Council } \\
\text { Koyuk } \\
\text { Kougarok } \\
\text { Fairhaven } \\
\text { Port Clarence }\end{array}$ & \begin{tabular}{r|}
18 \\
11 \\
11 \\
9 \\
10 \\
7
\end{tabular} & $\begin{array}{r}20 \\
21 \\
11 \\
14 \\
13 \\
5\end{array}$ & $\begin{array}{r}\$ 598,000 \\
449,000 \\
59,000 \\
50,000 \\
107,000 \\
7,000\end{array}$ & $\begin{array}{r}\$ 848,500 \\
217,600 \\
51,700 \\
31,600 \\
82,600 \\
13,000\end{array}$ \\
\hline & 66 & 84 & $1,270,000$ & $1,245,000$ \\
\hline
\end{tabular}

In the Nome district, in addition to the production from seven dredges, the greatest amount of gold came from ground on Little Creek that was hydraulicked by the Hammon Consolidated Gold Fields. Other creeks from which a considerable amount of gold in the aggregate was taken were Anvil, Boulder, and Last Chance, Osborn, Rock, and Sunset creeks, and from the old second beach line. The greatest production from the districts here grouped as the Solomon, Casadepaga, and Council districts came from six 
dredges. Five mines in the Solomon district, one in the Casadepaga, and nine in the Council district are the only other mines where productive work was in progress. In the Koyuk the greatest mining activity was on Dime and Sweepstakes creeks. Drift methods for underground mining of deposits are extensively used at several claims, especially on the lower part of Dime Creek and on some of the bench claims. The aggregate production from these drift mines is considerably greater than that from the properties in this district that are using other methods of mining. One dredge was operated during part of the season on Dime Creek. The placer deposits on Dime Creek are of special interest because some of them carry platinum metals.

Mining in the Kougarok district was carried on at 14 properties, two of which were mined by dredges. Even the largest of the mines operated by other mining methods than dredging produced only a few thousand dollars worth of gold. In the Fairhaven district the greatest amount of gold was mined by three camps on Inmachuk River. Considerable gold was recovered by two mines on Patterson Creek, two on Candle Creek, and one on Bear Creek. Some production was also reported from the new camp on Koopuk Creek, a tributary of the Buckland, but the general reports from that region are not so favorable for extensive developments as some had been led to expect from the earlier rumors.

Most of the placer gold mined in the Port Clarence district in 1924 came from mines of Dick, Coyote, and Gold Run creeks, although a very small amount was also obtained from placers on Windy Creek and Bluestone River.

Kobuk region.-In the Kobuk region three properties in the vicinity of Shungnak and one on Klery Creek produced a small amount of gold. Mining in the region as a whole appears to have been little more than prospecting. The records regarding the region, however, are far from complete, and most of the data used in preparing the foregoing estimates are based on information obtained from different sources, some of which do not appear to be fully reliable.

DREDGING

The use of dredges for winning gold from placers continued to be a highly successful method of mining. Although the general facts regarding the production by dredges have already been given in the general tables of placer production, it has been desirable to make special mention here of the work done during the year by the dredges. The amount of gold produced by this form of min- 
ing, in spite of the fact that two more dredges were in operation, decreased somewhat from the amount produced in 1923. The large new dredge of the Hammon Consolidated Gold Fields at Nome was not completed and in running order until October 7, so that it had a rather short season. The following list of the dredges and the different districts in which they were operated during the season of 1924 shows that there were 27 dredges operated in Alaska during that year, of which 16 were in Seward Peninsula, 9 in the Yukon basin, and one each in the Kuskokwim and Susitna basins:

Seward Peninsula:

Council district:

Northern Light Mining Co., Ophir Creek.

Wild Goose Mining \& Trading Co., Ophir Creek.

Mebes \& Hansen, Albion Creek.

Kougarok district:

Alaska Kougarok Co., Kougarok River.

Behring Dredging Corporation, Kougarok River.

Koyuk district: Dime Creek Dredging Co., Dime Creek.

Nome district:

Bangor Dredge Co., Anvil Creek.

Alaska Mines Corporation, Snake River.

Dexter Creek Dredging Co., Dexter Creek.

Hammon Consolidated Gold Fields (three dredges), on or near Little Creek.

A. H. Moore, Osborn Creek.

Solomon district:

Iversen \& Johnson, Big Hurrah Creek.

Lomen Reindeer \& Trading Corporation, Solomon River.

Shovel Creek Dredging Co. (Nylen, Hultberg, and others), Shovel Creek.

Yukon Basin:

Circle district: Berry Dredging Co., Mastodon Creek.

Fairbanks district:

Fairbanks Gold Dredging Co. (two dredges), Fairbanks Creek.

Chatham Gold Dredging Co., Cleary Creek.

Iditarod district:

North American Dredge Co., Otter Creek.

J. E. Riley Investment Co., Otter Creek.

Innoko district:

Flume Dredge Co., Yankee Creek.

Guinan \& Ames Dredging Corporation, Ganes Creek.

Innoko Dredging Co., Ganes Creek.

Kuskokwim region :

Mount McKinley district: Kuskokwim Dredging Co., Candle Creek.

Cook Inlet and Susitna region:

Yentna district: Cache Creek Dredging Co., Cache Creek.

About 45 per cent of Alaska's total production of gold from placers in 1924 was won by dredges. The following table shows 
the value of the gold recovered by dredges since this type of mining began in 1903:

Gold produced by dredge mining in Alasvia, 1903-1924

\begin{tabular}{|c|c|c|c|c|}
\hline Year & $\begin{array}{l}\text { Number of } \\
\text { dredges } \\
\text { operated }\end{array}$ & $\begin{array}{l}\text { Value of } \\
\text { gold } \\
\text { output }\end{array}$ & $\begin{array}{c}\text { Gravel } \\
\text { handled } \\
\text { (cubic } \\
\text { yards) }\end{array}$ & $\begin{array}{l}\text { Value of } \\
\text { gold re- } \\
\text { covered per } \\
\text { cubic yard }\end{array}$ \\
\hline \multirow[t]{2}{*}{19018} & \multirow[t]{2}{*}{$\begin{array}{r}34 \\
36 \\
28 \\
28 \\
22 \\
24 \\
23 \\
25 \\
27\end{array}$} & $\begin{array}{r}\$ 12,431,000 \\
2,679,000 \\
2,500,000 \\
1,425,000 \\
1,360,000 \\
1,129,932 \\
1,582,520 \\
1,767,753 \\
1,848,596 \\
1,563,361\end{array}$ & $\begin{array}{r}3,900,000 \\
3,700,000 \\
2,490,000 \\
1,760,000 \\
1,633,861 \\
2,799,519 \\
3,186,343 \\
4,645,053 \\
a 4,342,667\end{array}$ & $\begin{array}{l}.69 \\
.68 \\
.57 \\
.77 \\
.69 \\
.57 \\
.55 \\
.40 \\
. .36\end{array}$ \\
\hline & & $28,287,162$ & & \\
\hline
\end{tabular}

- See text (pp. 19-20) for basis of estimate.

The average length of the operating season for the dredges that furnished reports of their work was approximately 100 days, but there was wide variation in the extremes. So far as can be told from the incomplete records in hand, the Hammon Consolidated Gold Fields operated two of its dredges in the vicinity of Little Creek in the Nome district from May 1 to December 6, an operating season of 220 days. The two dredges that were operated the next longest period were both in the Iditarod region. One of these dredges reported operating from June 12 to November 17, and the other from June 1 to November 1, or 158 and 153 days, respectively. May 1 was the earliest date on which any dredges started work, and most of them did not begin until July and closed down in October.

Mining by dredges is less affected by variations in rainfall than almost any other type of mining, but this year several of the dredges reported considerable difficulty owing to rather sudden rises and falls in near-by streams which destroyed dams or made it necessary to dig an unusual depth in bedrock to keep the boats afloat.

For several years the Survey has prepared a statement regarding the amount of ground handled by the dredges during the year. This information has considerable interest and value, but in 1924 only 18 of the 27 reports of dredges that have come to the Survey have given data from which this information could be computed. Therefore, rather than to make estimates of the amount of yardage handled by the companies that did not report, it has seemed best to give only the amount actually stated by the 18 companies that reported. These companies dredged $3,476,656$ cubic yards of gravel and from that material obtained the equivalent of fine gold valued at $\$ 1,257,565$. The average recovery was therefore 36 cents a cubic yard. This is somewhat lower than the value of gold recovered by the dredges in 1923, when the average was 40 cents. If this factor 
of 36 cents applies to the ground of those companies that did not report, the total volume of the gravel dredged in 1924 was $4,342,667$ cubic yards, as compared with $4,645,053$ cubic yards handled by the dredges in 1923. On the whole, however, the dredges that reported the volume of gravel they had mined were those of the larger companies, and therefore they could handle profitably ground of lower tenor than the smaller dredges could. It therefore seems probable that the average fine gold recovered per cubic yard by the dredges that did not report and that is not included in the foregoing table probably was higher and might bring up the average per cubic yard. The total cubic yardage mined would then be less than the estimate given above, for that was computed by dividing the total gold output of the dredges by the average fine gold content.

A healthy sign in the undertaking of many of the newer dredging projects has been the more thorough examination of the ground in advance of any extensive outlay of money. Although mining enterprises necessarily face many uncertainties in actual operations, there are many factors which can be determined in advance, and neglect to determine them is bound to be detrimental. Among the most obvious, but in the past one of the most frequently disregarded factors, is the tenor and character of the ground to be dredged. Adequate sampling and testing by drilling well repay their cost and are now generally carried on extensively before any large new project is undertaken. Many of the smaller operators, however, who especially need this sort of information, still do not make adequate outlays for getting it.

\section{COPPER}

Copper ores are widely distributed in Alaska, but only in regions readily accessible to transportation have productive mines been developed. Even in those parts of Alaska near the coast many known prospects are still lying idle because of the lack of capital or because, at the present price of copper, the ore will not repay the high cost of necessary supplies and equipment. Copper was produced in 1924 mainly in the Chitina region of the Copper River basin by the Kennecott Copper Corporation, the Mother Lode Coalition Mines Co., and the Green Butte Copper Co.; on Latouche Island in Prince William Sound by the Kennecott Copper Corporation; and in the Ketchilkan district of southeastern Alaska by the Alaska Palladium Co. The relative order of their production is the order in which the districts are named. Altogether more than $74,000,000$ pounds of copper was produced from the different mines, and at the average price of copper that prevailed in 1924 the output was worth over $\$ 9,700,000$. This output came from lode mines whose dominant valuable mineral was copper and from a lode project 
near Seldovia, though a few thousand pounds of copper were also recovered from placer operations in the Copper River basin. In addition a little copper was recovered from lodes of the Strelna district, in which gold predominates, and from the silver-lead lode of the Kantishna district.

Copper, silver, and gold produced at Alaska copper mines, 1900-1924

\begin{tabular}{|c|c|c|c|c|c|c|c|c|}
\hline \multirow{2}{*}{ Year } & \multirow{2}{*}{$\begin{array}{c}\text { Mines } \\
\text { oper- } \\
\text { ated a }\end{array}$} & \multirow{2}{*}{$\begin{array}{c}\text { Ore mined } \\
(\text { tons })\end{array}$} & \multicolumn{2}{|c|}{ Copper } & \multicolumn{2}{|c|}{ Silver } & \multirow{2}{*}{ Gold } & \multirow{2}{*}{$\begin{array}{c}\text { Total } \\
\text { value of } \\
\text { metals }\end{array}$} \\
\hline & & & Pounds & Value & Fine ounces & Value & & \\
\hline \multirow[t]{2}{*}{$\begin{array}{l}1900-1915 . \\
1916 \\
1917 \\
1918 \\
1919 \\
1920 \\
1921 \\
1922 \\
1923 \\
1924\end{array}$} & \multirow[t]{2}{*}{$\begin{array}{r}18 \\
17 \\
17 \\
8 \\
8 \\
6 \\
5 \\
6 \\
5\end{array}$} & $\begin{array}{r}1,232,396 \\
617,264 \\
\mathbf{6 5 9}, 957 \\
722,047 \\
492,644 \\
766,095 \\
477,121 \\
581,384 \\
731,168 \\
761,779\end{array}$ & $\begin{array}{r}220,773,969 \\
119,654,839 \\
88,793,400 \\
69,224,951 \\
47,220,771 \\
70,435,363 \\
57,011,597 \\
77,967,819 \\
85,920,645 \\
74,074,207\end{array}$ & $\begin{array}{r}\$ 35,031,225 \\
29,484,291 \\
24,240,598 \\
17,098,563 \\
8,783,063 \\
12,960,106 \\
7,354,496 \\
10,525,655 \\
12,630,335 \\
9,703,721\end{array}$ & $\begin{array}{r}2,351,726 \\
1,207,121 \\
1,041,153 \\
719,391 \\
488,034 \\
682,033 \\
544,311 \\
623,518 \\
715,040 \\
572,078\end{array}$ & $\begin{array}{r}\$ 1,297,756 \\
794,286 \\
857,911 \\
719,391 \\
546,598 \\
743,416 \\
544,311 \\
623,518 \\
586,333 \\
383,292\end{array}$ & $\begin{array}{r}\$ 1,059,357 \\
188,977 \\
265,900 \\
107,635 \\
63,795 \\
18,868 \\
11,689 \\
15,069 \\
33,633 \\
13,341\end{array}$ & $\begin{array}{r}\$ 37,388,338 \\
30,467,554 \\
25,364,409 \\
17,925,589 \\
9,393,456 \\
13,722,390 \\
7,910,496 \\
11,164,242 \\
13,250,301 \\
10,100,354\end{array}$ \\
\hline & & $7,041,855$ & $911,077,561$ & $167,812,053$ & $8,944,405$ & $7,096,812$ & $1,778,264$ & $176,687,129$ \\
\hline
\end{tabular}

- Properties producing less than $\$ 1,000$ are not counted as mines but are considered prospects.

There was a decrease of more than $11,000,000$ pounds in the amount of copper produced in 1924 from the amount produced in 1923 , and as the average price of copper was 1.6 cents less in 1924 than in 1923 the value showed an even greater decrease. It should be remembered, however, that 1923 was marked by a rather unusually large production of copper in Alaska and that the production for 1924 was more than 5,000,000 pounds greater than the average production for the preceding six years. A large part of the decrease was due to lessened production by the Kennecott Copper Corporation, for, according to the statements in its published annual reports, the copper sold was 50,945,719 pounds in 1923 and 42,985,532 pounds in 1924. At the Kennecott mine of this company a serious fire early in August, 1924, destroyed part of the power plant, but by great efforts and marked engineering ingenuity the mine and mill were kept in almost continuous operation. A temporary power installation was practically completed before the end of September, so that there was only slight interruption. Two mines in southeastern Alaska that produced several hundred thousand pounds of copper in 1923-in part from old dumps and material that had been mined several years before-were not in operation in 1924 .

Prospecting and development work, according to Moffit, was continued at Rua Cove on Knight Island, at the Hemple property in Landlocked Bay, at one or two neighboring prospects on Landlocked and Fidalgo bays, and on Hogg Bay at the southwest end of Bainbridge Island. Except for annual assessment work on the clairns of the Hubbard-Elliott Copper Co. on Elliott Creek and on claims on 
Kotsina River there was no prospecting for copper in the western part of the Chitina Valley.

Buddington reports that work on the copper claims near Lake Bay in the Ketchikan region was continued.

In addition to copper the mines classed as copper mines produced some gold and a good deal of silver and palladium. The gold and silver from this source are included in the tables on pages 3 and 5 . The palladium is included under miscellaneous mineral products in the table on page 4 .

\section{SILVER AND LEAD}

Practically all the silver produced in Alaska in 1924 was a byproduct from the gold lodes and placers and from the copper lodes. Nearly all the lead came from deposits classified as gold lodes. One mine, however, was operated primarily for the silver and lead contained in its ore. This mine was the Alpha mine in the Kantishna district, but as its output was small and could not be listed separately without disclosing confidential information, it has been tabulated as one of the gold mines and is so treated in the following statements.

The following records show the amount of silver and lead recovered from the various types of mines classified according to the dominant valuable mineral they contain.

Silver and lead obtained from gold lodes, gold placers, and copper lodes in 1924

\begin{tabular}{|c|c|c|c|c|}
\hline & \multicolumn{2}{|c|}{ Silver } & \multicolumn{2}{|c|}{ Lead } \\
\hline & Ounoes & Value & Pounds & Value \\
\hline \multirow{3}{*}{$\begin{array}{l}\text { Gold lodes } \\
\text { Gold placers: } \\
\text { Dredges. } \\
\text { Others } \\
\text { Copper lodes............ }\end{array}$} & 75,284 & $\$ 50,440$ & $1,261,239$ & $\$ 100,899$ \\
\hline & $\begin{array}{r}13,007 \\
572,078\end{array}$ & $\begin{array}{r}0,212 \\
88,715 \\
383,292\end{array}$ & 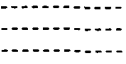 & . \\
\hline & 669,641 & 448,659 & $1,261,239$ & 100,899 \\
\hline
\end{tabular}

The silver obtained from the gold lodes came from 19 mines and a few prospects; that from the gold placers from 540 mines; and that from the copper lodes from 5 mines. The lead was obtained from 6 lode mines or prospects. According to the table on page 6, which was compiled from the published annual reports of the Alaska Juneau Gold Mining Co., that company's mine at Juneau alone produced $1,256,857$ pounds of lead.

Although, as noted above, only one small silver-lead mine reported production in 1924, at several mines the development work that was being done should soon result in adding new names to the list of producers and materially swell the yield of these metals. According to A. F. Buddington, prospecting in the vicinity of Hyder has dis- 
closed ore that is sufficiently rich to lead the owners of one property, the Riverside, to feel justified in going ahead with the construction of a mill, and promising ore has been found at several other prospects in the district. Additional notes on this district are contained in a paper by Mr. Buddington that forms a later part of this report. A detailed survey of the region was undertaken near the close of the fiscal year 1925 by Mr. Buddington, and a summary statement of the results will probably be available for inclusion in the next progress report.

Prospecting for silver-lead lodes was also in progress in the Wrangell district on the Lake claims.

Further development work on certain of the silver-lead claims in the Kantishna district has uncovered ore that will probably reach the market in 1925 .

An examination of an interesting ruby silver lode in the upper Susitna basin about 9 miles east of Chulitna station on the Alaska Railroad was made by S. R. Capps. He states that too little development work to permit an estimate of the size and value of the ore body has yet been done. A picked sample of the ore, however, tested by the Bureau of Mines, showed a silver content of nearly 120 ounces of silver to the ton, although selected samples, cut continuously across the vein, according to the best mining practice, showed less than 33 ounces of silver to the ton. A complete statement of Mr. Capps's observations, together with notes on the laboratory examination of the material by M. N. Short, is given in another chapter of this bulletin.

A silver-lead prospect situated about 14 miles south of Ruby was visited by J. S. Brown, who believes that the amount of ore so far discovered is too small to justify the risk of further expenditure in that place under present conditions. However, he says that similar surface outcroppings in that region justify at least sufficient prospecting to determine their size and richness. The full statement of Mr. Brown's observations regarding this prospect form a later chapter in this bulletin.

Lead produced in Alaska, 1892-1924

\begin{tabular}{|c|c|c|c|c|c|c|c|c|}
\hline Year & Tons & Value & Year & Tons & Value & Year & Tons & Value \\
\hline $\begin{array}{l}1892 \\
1893 \\
1894 \\
1895 \\
1896 \\
1897 \\
1898 \\
1899\end{array}$ & $\begin{array}{l}30 \\
40 \\
35 \\
20 \\
30 \\
30 \\
30 \\
35 \\
40\end{array}$ & $\begin{array}{r}\$ 2,400 \\
3,040 \\
2,310 \\
1,320 \\
1,800 \\
2,160 \\
2,240 \\
3,150 \\
3,440\end{array}$ & $\begin{array}{l}1904 \\
1905 \\
1906 \\
1907 \\
1908 \\
1909 \\
1910 \\
1911\end{array}$ & $\begin{array}{l}30 \\
30 \\
30 \\
30 \\
40 \\
69 \\
75 \\
51 \\
45\end{array}$ & $\begin{array}{r}\$ 2,580 \\
2,620 \\
3,420 \\
3,180 \\
3,360 \\
5,934 \\
6,600 \\
4,590 \\
4,050\end{array}$ & $\begin{array}{l}1916 \\
1917 \\
1918 \\
1919 \\
1921 \\
1922 \\
1923 \\
1924\end{array}$ & $\begin{array}{l}820 \\
852 \\
564 \\
687 \\
875 \\
759 \\
377 \\
410 \\
631\end{array}$ & $\begin{array}{r}\$ 113,160 \\
146,584 \\
80,088 \\
72,822 \\
140,000 \\
68,279 \\
41,477 \\
57,400 \\
100,890\end{array}$ \\
\hline 1901 & $\begin{array}{l}40 \\
30 \\
30\end{array}$ & $\begin{array}{l}3,440 \\
2,460 \\
2,520\end{array}$ & 1913 & $\begin{array}{r}0 \\
28 \\
437\end{array}$ & $\begin{array}{r}528 \\
1,344 \\
41,118\end{array}$ & & 7,236 & 930,313 \\
\hline
\end{tabular}


places in the tables on pages 3,5 , and 21 . The general geology and mineral composition of this lode has been described by Mertie, ${ }^{5}$ who states that the country rock is a basic intrusive igneous rock (pyroxenite), in which the ore minerals are distributed in grains and small patches as ore shoots, but that the ore deposit was formed later than the inclosing rock.

Nowhere in Alaska have the platinum metals been found in placers in sufficient quantities to make their recovery for themselves alone profitable. Platinum metals, however, were obtained from concentrates that were recovered from gold placer mining operations on Dime Creek in the Koyuk district of Seward Peninsula; on Slate Creek in the Chistochina district, Copper River basin; on Granite Creek in the Ruby district; and on Metal Creek in the Kenai Peninsula. Altogether 28 ounces of crude platinum metals, equivalent to 21.98 ounces of fine platinum metals, was recovered from these placer deposits. The value of these metals, computed as worth $\$ 118$ for each fine ounce, is $\$ 2,594$. This production is somewhat less than that in the last few years, for in 1921, 1922, and 1923 the production of fine platinum metals from these placers was $40,28.3$, and 25.9 ounces, respectively.

The bedrock source of the platinum metals found in the placers is not definitely known, though it was probably in the basic igneous rocks, usually of dark-green color and of high specific gravity. The discovery of the bedrock source is not likely unless search is specially directed toward this object. When it is remembered that in the Dime Creek region only about 1 ounce of platinum is found to 125 to 300 ounces of gold, the carefulness with which the search must be conducted will be apparent. This same general relation between the platinum metals and gold prevails in the other placer platinum deposits of Alaska.

\section{MISCELLANEOUS METALS}

The demand that arose during the war for many of the less common ores has subsided to such an extent that practically none of the Alaskan deposits of such minerals as those containing antimony, tungsten, chromium, and molybdenum shipped any ore during 1924. A small production of quicksilver from the Thrift mine, in the Iditarod-Kuskokwim region, was reported. This mine is about 23 miles north of the Crooked Creek landing on Kuskokwim River. The old furnace, which had four tubes, broke down soon after it was started late in 1924, but all the equipment necessary for the construc-

\footnotetext{
5 Mertle, J. B., jr., Lode mining in the Juneau and Ketchikan districts: U. S. Geol. Survey Bull. 714, pp. 121-127, 1921.
} 
tion of a new 12-tube mill, with a rated capacity of 5 tons a day, has been delivered and will be installed as soon as possible next season. Developments at the mine are reported to be progressing satisfactorily, and the ore at the depth reached by the shaft that is being sunk is said to be fully as good as that found near the surface.

Buddington reports that some prospecting was done on several molybdenite claims at various places on Lemesurier Island in Cross Sound, southeastern Alaska, especially near Willoughby Cove. Fuller notes on the geology of these deposits is given in the report by Buddington in a later chapter of this bulletin. Interest has continued in the prospecting and development of some nickelbearing deposits on Chichagof, Baranof, and Yakobi Islands. These deposits were recently described by Buddington, ${ }^{8}$ who states that most of the deposits are associated with basic intrusive igneous rocks (norite, gabbro) and that the geology of the region adjacent to some of the deposits bears a close similarity to that of the great nickel deposits at Sudbury, Ontario. No nickel ore from these mines, however, was reported to have been smelted in 1924.

Development work is reported to have been continued on a bismuth-bearing lode in the hills on Eva Creek, Nenana district, a few miles east of the railroad.

\section{COAL}

The most extensive coal mining in Alaska was in the Matanuska and Healy River fields, adjacent to the Alaska Railroad. The coals that are being mined in the Matanuska field are high-grade bituminous coals, whereas those mined in the Healy River field are lignites. Four mines in the Matanuska field and two in the Healy River field reported some production of coal during the year. In addition, a small amount of subbituminous coal was mined by Eskimos from outcrops along the shores of Wainwright Inlet in northern Alaska, and a little lignite was mined for local use on Kugruk River in Seward Peninsula. The total coal produced from all these sources was 99,663 tons, valued at approximately $\$ 600,000$. Too great reliance should not be placed on the statement of the value, for the prices used in the computations were based in part on the contracts placed by the Alaska Railroad for relatively large orders. For the fiscal year 1924 the railroad bought over 60,000 tons of coal of all grades, from all fields, at an average price of $\$ 5.63$ a ton, and the contract prices for coal from the Matanuska field for the fiscal year 1925 were $\$ 7.50, \$ 5.80$, and $\$ 5.25$ a ton, respectively, for lump, fine,

- Buddington, A. F., Mineral investigations in southeastern Alaska: U. S. Geol. Survey Bull. 773, pp. 95-113, 1925. 
and steam sizes, and for coal from the Healy River field $\$ 4.25, \$ 3.50$, and $\$ 2.50$, respectively, for similar sizes.

In spite of the fact that Alaska contains vast stores of coal and in spite of the fact that many of the coal mines could produce each year more coal than they now do, a great deal of the local market is still supplied by coals imported mainly from British Columbia and from the State of Washington. In 1924 nearly 45 per cent of the coal used in Alaska was imported. If the amount of coal used in the maintenance of the Alaska Railroad is deducted from the total amount used in the Territory it will be seen that the present Alaskan production is practically the same as it was six or eight years ago, before the railroad was built, and that about the same amount of coal was imported then as now.

Coal produced and consumed in Alaska, 1880-1924

\begin{tabular}{|c|c|c|c|c|c|}
\hline \multirow[b]{2}{*}{ Year } & \multicolumn{2}{|c|}{$\begin{array}{l}\text { Produced in Alaska, } \\
\text { chiefy subbitumi- } \\
\text { nous and lignite }\end{array}$} & \multirow{2}{*}{$\begin{array}{l}\text { Imported } \\
\text { from } \\
\text { States, } \\
\text { chiefly } \\
\text { bitu- } \\
\text { minous } \\
\text { coal from } \\
\text { Wash- } \\
\text { ington a } \\
\text { (short tons) }\end{array}$} & \multirow{2}{*}{$\begin{array}{c}\text { Imported } \\
\text { from } \\
\text { foreign } \\
\text { countries, } \\
\text { chiefly } \\
\text { bituminous } \\
\text { coal from } \\
\text { British } \\
\text { Columbia } \\
\text { (short tons) }\end{array}$} & \multirow[b]{2}{*}{$\begin{array}{l}\text { Total coal } \\
\text { consumed } \\
\text { (short tons) }\end{array}$} \\
\hline & Short tons & Value & & & \\
\hline \multirow[t]{2}{*}{$\begin{array}{l}1880-1915 \\
1916 \\
1917 \\
1919 \\
1920 \\
1921\end{array}$} & $\begin{array}{r}71,633 \\
12,676 \\
54,275 \\
75,816 \\
60,894 \\
61,111 \\
76,817 \\
79,275 \\
119,826 \\
99,663\end{array}$ & $\begin{array}{r}\$ 456,993 \\
57,412 \\
268,438 \\
413,870 \\
345,617 \\
355,668 \\
496,394 \\
430,639 \\
755,469 \\
559,980\end{array}$ & $\begin{array}{r}679,844 \\
44,934 \\
58,116 \\
51,520 \\
57,166 \\
38,128 \\
24,278 \\
28,457 \\
34,082 \\
40,161\end{array}$ & $\begin{array}{r}1,079,735 \\
53,672 \\
56,589 \\
37,986 \\
48,708 \\
45,264 \\
33,776 \\
34,251 \\
43,205 \\
41,980\end{array}$ & $\begin{array}{r}1,814,047 \\
11,282 \\
168,980 \\
165,322 \\
166,768 \\
144,503 \\
134,871 \\
141,983 \\
197,113 \\
181,804\end{array}$ \\
\hline & 711,986 & $4,140,480$ & $1,056,686$ & $1,475,166$ & $3,226,673$ \\
\hline
\end{tabular}

a Compi ad from Monthly Summary of Foreign Commerce of the United States, 19051924, Bure.u of Foreign and Domestic Commerce. No figures on imports before 1899 are available.

Some exploratory work was done during the year on the highgrade coal of the Matanuska and Bering River fields, though none of this coal was marketed. S. R. Capps, of the Geological Survey, who studied the coal fields of the upper Matanuska Valley, reports that the coal-bearing area on the south flank of Anthracite Ridge contains beds carrying excellent anthracite coal, which is exposed at many places. At a place on the head of West Fork of Purinton Creek a bed of anthracite nearly 40 feet thick crops out. In this area, however, the coal-bearing formation is highly disturbed by folding, crumpling, and faulting, as well as intruded by bodies of igneous rock, such as dikes and sills. The coal beds appear to lie in synclinal basins, most of the upper part of the folds having been removed by erosion. These beds no doubt contain considerable an- 
thracite coal of high grade, but whether the beds are sufficiently large and continuous to justify the expense of mining is uncertain in view of the cost of building a railroad to the area. Very little prospecting has been done on the anthracite beds, and whether they include workable bodies's of coal can be proved only by extensive exploration, both on the surface and underground. The complete report by Mr. Capps is now awaiting publication by the Survey, but no definite date for its issue can yet be set.

The parties engaged in exploring Naval Petroleum Reserve No. 4 in northern Alaska in 1924 report a great extension of the coal fields previously known in the coastal region near Cape Lisburne. The coal-bearing rocks extend eastward through the central part of the reserve and evidently carry an enormous quantity of bituminous or subbituminous coal.

Some idea of the amount of coal available may be obtained from the measurements on Kukpowruk and Utukok rivers, where of 69 coal outcrops 30 contained minable beds of coal 3 feet or more thick. and aggregating 187 feet of coal. This region is so remote that there is little likelihood of any of its coal being used in the near future except locally. However, in a region where trees are entirely absent this fuel has a special value, and the coal will doubtless play an important part in making possible the development of any oil resources that may be discovered in the region. A comprehensive report on the coals, as well as the other geologic information on this northern country, is in preparation, but it will probably be a year or more before it is published. A statement regarding the results of the work done in the region in 1923 , however, has been printed, ${ }^{7}$ and a summary statement which deals mainly with the possibilities of the presence of oil forms another chapter of this bulletin.

\section{PETROLEUM}

The Katalla field, situated near the south-central coast of Alaska, still continues to be the only producing oil field of the Territory. The oil produced here in 1924 came from 16 small wells, all on patented claims owned by the Chilkat Oil Co. The oil is refined at the company's own plant and is marketed in the form of gasoline and distillate, which has a ready sale and is said to be of especially high grade. No new wells were completed and no old wells were abandoned during the year. The quantity and value of the petroleum produced has been included in the table on pages $3-4$, under the heading "Miscellaneous mineral products."

7 Paige, Sidney, Foran, W. T., and Gilluly, James, A reconnaissance of the Point Barrow region, Alaska: U. S. Geol. Survey Bull. 772, v, 33 pp., 9 pls., 1925. 
Petroleum products shipped to Alaska from other parts of the United States, 1905-1924, in gallons ${ }^{a}$

\begin{tabular}{|c|c|c|c|c|}
\hline Year & $\begin{array}{l}\text { Heavy oils, } \\
\text { including } \\
\text { crude oil, gas } \\
\text { oil, residuum, } \\
\text { etc. }\end{array}$ & $\begin{array}{c}\text { Gasnline, } \\
\text { including all } \\
\text { lighter } \\
\text { products of } \\
\text { distillation }\end{array}$ & $\underset{\text { oil }}{\text { Illuminating }}$ & $\begin{array}{l}\text { Lubricating } \\
\text { oil }\end{array}$ \\
\hline \multirow[t]{2}{*}{$\begin{array}{l}1905 \\
1906 \\
1908 \\
1910 \\
19112\end{array}$} & $\begin{array}{r}2,715,974 \\
2,688,940 \\
9,104,300 \\
11,891,375 \\
14,119,102 \\
19,143,091 \\
20,878,843 \\
15,523,555 \\
15,682,412 \\
18,601,384 \\
16,910,012 \\
23,555,811 \\
23,971,114 \\
24,379,566 \\
18,784,013 \\
21,981,569 \\
9,209,102 \\
15,441,542 \\
12,285,808 \\
14,412,120\end{array}$ & $\begin{array}{r}713,496 \\
580,978 \\
636,831 \\
939,424 \\
746,930 \\
788,154 \\
1,238,865 \\
2,736,739 \\
1,735,658 \\
2,878,723 \\
2,413,962 \\
2,844,801 \\
3,256,870 \\
1,086,852 \\
1,007,073 \\
1,764,302 \\
1,403,683 \\
1,436,050 \\
4,882,015 \\
5,554,859\end{array}$ & $\begin{array}{r}627,391 \\
568,033 \\
510,145 \\
566,598 \\
531,727 \\
620,972 \\
423,750 \\
672,176 \\
661,656 \\
731,146 \\
513,075 \\
732,369 \\
750,238 \\
382,186 \\
3,515,746 \\
887,942 \\
2,021,033 \\
2,095,675 \\
473,826 \\
566,431\end{array}$ & $\begin{array}{r}83,319 \\
83,992 \\
100,145 \\
94,542 \\
85,687 \\
104,512 \\
100,141 \\
154,565 \\
150,918 \\
191,876 \\
271,981 \\
373,046 \\
465,693 \\
362,413 \\
977,703 \\
412,107 \\
232,784 \\
345,400 \\
454,090 \\
506,, 364\end{array}$ \\
\hline & $311,279,633$ & $38,646,315$ & $17,852,115$ & $5,551,278$ \\
\hline
\end{tabular}

a Compiled from Monthly Summary of Foreign Commerce of the United States, 1905 to 1924, Bureau of Foreign and Domestic Commerce.

The search for oil in the Alaska Peninsula still continues. W. R. Smith, of the Geological Survey, who visited this region during the field season of 1924, reports that drilling in the Cold Bay district was continued on the Pearl Creek dome by the Standard Oil Co. of California, whose Lee No. 1 well had been drilled to a depth of 3,017 feet, where it struck a rather strong flow of water and some gas. The Associated Oil Co. suspended drilling at a depth of 950 feet in June, 1923, but renewed operations in June, 1924, and continued drilling during the remainder of the year. The latest reported depth of the Associated well is 2,170 feet. Although drilling has been carried on with difficulty at considerable expense, and to a greater depth than was at first considered necessary, both wells have given showings of oil, and the companies expect to test the dome thoroughly. The Government road from Kanatak to Becharof Lake was completed late in the fall of 1923 and was used during the summer of 1924 by the operating companies. The new road does not shorten the distance to the wells, but it avoids a hard climb over the mountains. A few claims were surveyed during the summer. A more complete statement by W. R. Smith regarding the geology and oil developments in this region, accompanied by a structure contour map of the Salmon Creek-Bear Creek anticline, forms a later chapter of this bulletin.

The search for oil in Naval Petroleum Reserve No. 4, in the extreme northern part of Alaska, is still being continued by the Gov- 
ernment through parties sent out by the Geological Survey. A report ${ }^{8}$ covering the work of the Survey parties in 1923 in the region has already been printed, but the results obtained in 1924 will be included with the work of parties now in the field and will not be published in separate form. The interest in this northern field, however, has led to the preparation of a summary statement of the present knowledge regarding the possibilities of the presence of petroleum in the region, and this statement forms a separate chapter of this volume.

\section{STRUCTURAL MATERIALS}

Shipments of marble from southeastern Alaska began in 1902, and since 1904 quarrying has been an important industry. Most of the marble produced has come from the north end of Prince of Wales Island, where the only large quarries (those of the Vermont Marble Co.) are located. There are, however, many other places in southeastern Alaska where marble has been found. The broad geologic relations of some of these other localities for marble and limestone are discussed in a paper by A. F. Buddington, which forms a chapter of this bulletin. The value of the marble produced in 1924 was somewhat greater than in 1923.

The only commercial deposit of gypsum which has been found in Alaska is on the eastern shore of Chichagof Island, in the Sitka district. Gypsum has been quarried at this place every year since 1906, but the mine then operated by the Pacific Coast Gypsum $\mathrm{Co}_{\text {。 }}$ was closed down in December, 1923, and remained idle until August, 1924, when it was taken over by the Standard Gypsum Co. Since that time the main activity has consisted in prospecting the ground and laying out plans for a new mill and the development of the mina. For these reasons the production in 1924 was very much less than in the preceding year.

\footnotetext{
${ }^{8}$ Paige, Sidney, Foran, W. T., and Gilluly, James, op. cit.
} 


\title{
ADMINISTRATIVE REPORT
}

\author{
By Philip S. Sмiтн
}

\section{REVIEW OF THE WORK OF THE YEAR}

Systematic investigations and surveys of Alaskan mineral resources have been carried on uninterruptedly by the Geological Survey since 1898, and even before that year some of the geologists and engineers of the Survey had been assigned to special investigations within the Territory. During this period of more than a quarter of a century about two-fifths of Alaska has been mapped and all the larger known mineral deposits have been studied to some extent. Practically all of this work was organized, administerel, and largely participated in by Alfred H. Brooks, chief Alaskan geologist, who died suddenly November 22, 1924. Mr. Brooks, through his long experience, sympathetic understanding of the problems of the mineral industry in a frontier country, and broad technical knowledge, was in large measure personally responsible for the application of sound scientific principles to the search for and development of the Territory's mineral resources. S. R. Capps served as acting chief Alaskan geologist after the death of Mr. Brooks until March 31, 1925, and on April 1, 1925, Philip S. Smith was designated to take charge of the branch.

The following table indicates the areas that have been geologically and topographically mapped by the Geological Survey. The figures, of course, do not include any surveys in Alaska conducted by other Government organizations.

Areas surveyed by Geological Survey in Alaska, 1898-1925, in square miles

\begin{tabular}{c|r|r|r|r|r|r}
\hline \multirow{2}{*}{ Fiscal year } & \multicolumn{2}{|c|}{ Areas covered by geologic surveys } & \multicolumn{2}{|c|}{ Areas covered by topographic } \\
surveys
\end{tabular}

$78644^{\circ}-26-3$ 
In this summary table only the net areas surveyed in earlier years are given. Furthermore, an area that has been surveyed on more than one scale is tabulated only in the column for the largest scale on which it has been mapped. For instance, the region adjacent to Nome, which in the early days was surveyed on an exploratory scale, later mapped on a reconnaissance scale, and still later on a detailed scale, is reported only as covered by detailed mapping. Therefore there is no duplication of areas reported under the different kinds of geologic or topographic surveys. On the whole, the areas covered by geologic surveys are coincident with those covered by topographic surveys, so that nearly two-thirds of the Territory has not yet been mapped by the Geological Survey.

Many of the surveys and investigations of Alaskan mineral resources, however, do not readily lend themselves to tabulation in terms of area or other intercomparable units of measurement. Among such studies may be mentioned the collection of statistics regarding the annual production of the different ores and minerals or the bringing together in one report all available data regarding the known oil or coal resources of the Territory. Furthermore, for several years the Geological Survey conducted investigations relating to the water resources of the Territory, maintaining at times as many as 80 gaging stations and making each year several hundred stream measurements.

The funds directly appropriated for the Survey's Alaskan work that were available for the fiscal year 1925 comprised $\$ 75,000$ carried in the Interior Department bill for 1925, which became immediately available on the signing of the act, June 5; 1924, and $\$ 72,000$ carried in the Interior Department appropriation act for the fiscal year 1926, which became available March 3, 1925. In addition a transfer of funds amounting to $\$ 75,000$ was made available to the Survey by the Navy Department for the continuation of the investigation of Naval Petroleum Reserve No. 4, in northern Alaska. Two of these appropriations were legally available for expenditure and some money was expended from both during the fiscal year 1924; all three of them were available and used to pay for expenses during the fiscal year 1925; and the balance of the Navy funds and the regular 1926 appropriation are available for expenditures during the fiscal year 1926. The expenditures from all these funds have been accounted for under the methods and procedure laid down by law or by the regulations of the Treasury Department, but these methods do not lend themselves to showing the costs during a field season or concerning individual projects. The labor and expense of determining the precise expenditures for the different jobs by years would far exceed the value of the resulting analysis, and therefore these expenditures have not been accurately computed. The follow- 
ing statements give only in round figures the principal uses to which the funds were put during the fiscal year 1925. The amount expended in starting off the parties in advance of the beginning of the fiscal year in the field season of 1924 practically offset the amount used to start the parties at the end of the fiscal year 1925 to begin the work of the field season of 1925 . Thus, except for the work financed by the Navy Department, which will be analyzed separately, the funds used for the fiscal year 1925 were $\$ 75,000$.

The following table shows the approximate allotment for salaries and field and office expenses for the fiscal year 1925 :

Expenditures from funds directly appropriated for Survey's work in Alastia

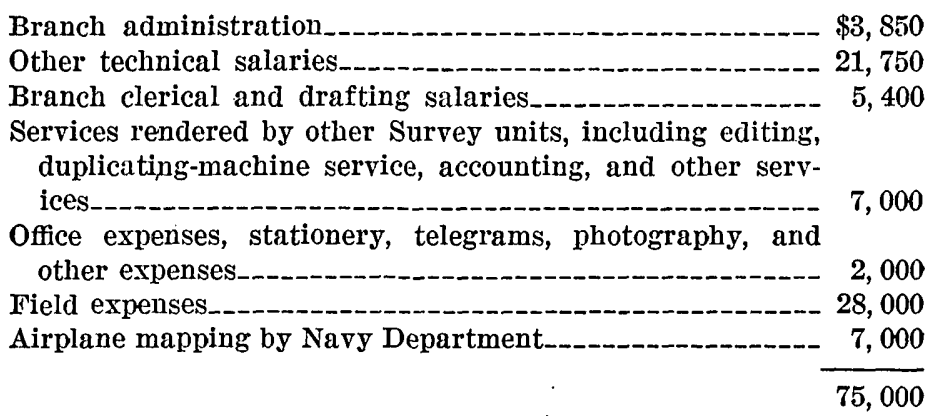

An analysis of the allotment of the $\$ 75,000$ transferred to the Geological Survey by the Department of the Navy is as follows:

Allocation of funds for surveys in Naval Petroleum Reserve No. 4, northern Alaslia

Administration $\$ 2,500$

Other technical salaries

Clerical and drafting salaries 3,300

Services rendered by other Survey units, including editing, accounting, instruments, and other services. 2,900

Office expenses, including stationery, photography, telegrams, and other expenses.

Field expenses_........ 36, 000

Allotted to work in progress for fiscal year 1926_........ 11, 000

Balance for contingencies

The items in the table regarding Alaskan branch expenditures for "other technical salaries, field expenses, airplane mapping" and $\$ 1,500$ of the item for clerical salaries, amounting in all to $\$ 58,250$, have been allotted for the different kinds of surveys and investigations in progress during the fiscal year 1925, as follows:

General investigations_-_-_-_- $\$ 3,750$

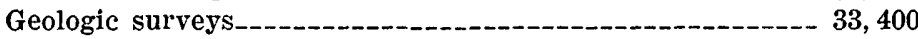

Topographic surveys

Statistics of mineral production 
It has been impossible to show accurately in the foregoing table the expense that should appropriately be distributed to topographic and geologic surveys, for two parties were engaged in work of both kinds. Each of these parties cost between $\$ 6,000$ and $\$ 7,000$, and their principal work was topographic mapping, so that, except for the geologists' salaries and a few hundred dollars spent for their traveling and subsistence, the whole amount might properly be included in the item for topographic surveys. On the other hand, the parties obtained many geologic data that could not have been obtained by separate geologic parties except at an additional expense of at least $\$ 3,000$ a party. In spite of the uncertainty, it has seemed best to divide the field expenses of both parties equally between topographic and geologic surveys, though by so doing geologic surveys bear perhaps an unduly heavy charge; or, to state the matter in another way, the economy of $\$ 6,000$ to $\$ 7,000$ effected by attaching geologists to the topographic parties is not adequately reflected by the table.

The different kinds of work reported in the foregoing table were carried on in many parts of Alaska. The following table indicates the approximate distribution of the work by geographic divisions for the fiscal year:

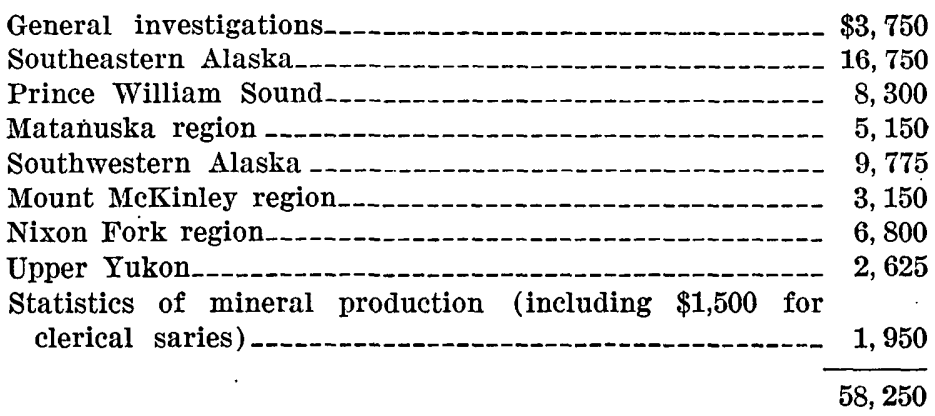

The work that has been segregated in the two preceding tables under the heading "General investigations" comprises four separate studies. One was the study of the broader aspects of the general geologic history of Alaska as affording an insight into the origin and distribution of mineralization. This work was carried on by Alfred $\mathrm{H}$. Brooks and is part of a comprehensive study to which all the detailed investigations have contributed. The field areas specially visited during the year were in southeastern Alaska, in the Prince William Sound region, and in the country adjacent to the Alaska Railroad. A little time was devoted by James McCormick to his revision of the "Geographic dictionary of Alaska," a valuable Survey publication issued in 1906, which has been out of stock for many years. The other two projects were paleontologic investigations required in correlating the fossils brought in by the different 
geologists from their field investigations. The study of the fossil flora of the Tertiary rocks, to which Arthur Hollick devoted about three months, is of special importance in correctly interpreting certain of the coal formations. The other paleontologic studies related principally to the older rocks, mainly Paleozoic, and were of great value in furnishing data used by the geologists in investigating deposits of metalliferous minerals.

Five distinct projects were undertaken in southeastern Alaska, two of which were executed during the field season of 1924 and the others during the field season of 1925 . In the field season of 1924 A. F. Buddington continued geologic studies in the Ketchikan and Wrangell regions, visiting many of the mines and prospects, including those in the Hyder district, at the head of Portland Canal. He collected many new data regarding the general geology of southeastern Alaska in relation to the ore deposits and did additional reconnaissance geologic mapping, especially on the southwest coast of Prince of Wales Island. A summary of the results of his work appears as a separate chapter in this volume.

In the same season R. M. Wilson continued the detailed topographic mapping of the Hyder district that had been started during the preceding fiscal year by E. S. Rickard, who was injured in the course of his duty in the field. The field surveys were completed, and after the office work, which required the computation of numerous topographic data from photographs, was finished, Mr. Wilson returned to his former duties with the topographic branch.

For the field season of $1925 \mathrm{Mr}$. Buddington has been detailed to map the geology of the hitherto unsurveyed areas in the extreme southwestern part of the Ketchikan region and then to do the detailed geologic surveying of the area topographically mapped by Mr. Wilson in the Hyder district. Only a portion of this work will be completed during the fiscal year, but it will be continued in the next fiscal year. ${ }^{1}$

R. K. Lynt left late in May, 1925, to do some reconnaissance topographic mapping in the Ketchikan district and then to join a party of surveyors from the General Land Office who are carrying on subdivisional surveys in the vicinity of Wrangell Narrows, where Mr. Lynt will make a detailed topographic map.

Negotiations have been in progress for several months with the Air Service of the War Department and later with the Bureau of Aeronautics of the Navy Department for the airplane photographing of the islands of southeastern Alaska, in the belief that the resulting prints would greatly expedite the topographic mapping

\footnotetext{
${ }^{1}$ The reader's attention is called to the fact that this report was written and submitted as of June 30,1925 . Many of the projects which are mentioned as in progress will have been completed before this report is issued, since considerable delay in printing is unavoidable.
} 
of the region and facilitate determination of the geology and mineral resources. The Navy Department agreed to do this work, and $\$ 7,000$ was turned over to it for that purpose under the fortifications act. The work will be done as soon as the necessary preparations can be completed. No field operations have been in progress this year under this grant, but ultimately it will furnish photographs of probably 18,000 square miles. It is hoped that this aerial survey may be the forerunner of surveys in some of the coastal tracts in other parts of Alaska that are traversable on foot with great difficulty and at a cost so high that their survey is not warranted under present conditions.

In the Prince William Sound region F. H. Moffit continued during the field season of 1924 the study of the ore deposits and related geology of the western part of the Sound and visited Valdez, Cordova, and the Kennicott region, in the Copper River basin, for the purpose of keeping in touch with recent developments bearing on mineral resources; he returned to Washington in the fall to work up his field notes. Mr. Moffit again left for the same general region in May, 1925, and will continue the reconnaissance geologic mapping not only to the end of this fiscal year but also into the next.

S. R. Capps spent the field season of 1924 in the upper Matanuska region, with $\mathbf{K}$. K. Landes as geologic assistant, mapping in detail the extension of the coal-bearing rocks and determining the geologic history of the region as it bears on the other mineral resources of that area. Mr. Capps has completed a manuscript report on this work which is now in hand for critical examination with a view to its publication as a bulletin. Late in this fiscal year, in the field season of 1925, Mr. Landes was assigned to complete the reconnaissance geologic mapping of an unsurveyed area between Matanuska and Knik rivers that is known to hold promise of deposits of metallic minerals of value, and the results of his work will probably throw light on the general geology of a large tract of contiguous territory.

In southwestern Alaska during the field season of 1924 W. R. Smith carried on reconnaissance geologic mapping of an area previously topographically surveyed in the Cold Bay region. This region is a part of the Alaska Peninsula where geologic indications favorable for the accumulation of oil pools have been reported and considerable activity has been displayed in prospecting. A preliminary report on the geology and mineral resources of the region forms part of this bulletin. In February, 1925, Mr. Smith left Washington to serve as geologist in the explorations being conducted in northern Alaska in Naval Petroleum Reserve No. 4.

In the field season of $1925 \mathrm{R}$. H. Sargent, topographer, and R. S. Knappen, geologist, will continue previous surveys of Alaska Peninsula southwestward from a point near Cold Bay to Chignik. It is 
expected that these surveys will practically complete the reconnaissance examination of the probable oil-bearing areas of the peninsula, as farther west igneous rocks probably form most of the country.

The surveys in the Nixon Fork region of the Kuskokwim were in charge of R. H. Sargent, with J. S. Brown, geologist. These surveys were made during the field season of 1924. A general doscription of the geology of the region has been prepared and transmitted for publication as part of this volume.

A geologic reconnaissance party in charge of S. R. Capps during the field season of 1925 examined the country adjacent to Mount McKinley, especially those parts which, from earlier exploratory surveys and reports of prospectors, are believed to contain metallic minerals of value. In addition to these surveys Mr. Capps will probably visit some of the mining camps in the Kantishna and Chulitna districts to obtain data on recent mining developments.

J. B. Mertie, jr., for all of the fiscal year until April, 1925, was engaged in naval petroleum work in northern Alaska. In May, 1925 , he left Washington to carry on geologic investigations in the region lying on both sides of Yukon River westward from the international boundary as far as Circle. Although his party will study many places that have not been hitherto examined by Survey geologists, the main purpose of the work is to correlate all the observations that have been made in the region, some of which are not in accord and most of which have not been reviewed in the light of more complete and detailed geologic information that has been accumulated both from this region and from other parts of the Territory since the original observations were made.

All the projects above described that were started late in this fiscal year during the field season of 1925 will be continued into the fiscal year 1926. Most of the parties are out of reach of ordinary means of communication, so that it is not possible at this time to state just what part of the different projects each accomplished this fiscal year. On the whole, however, much of the time will have been spent in getting to the field and starting the work, so that at most each party has spent less than a month in actual surveys. In other. words, as the usual field season is about a hundred days, the parties have probably completed approximately one-quarter of the field work of their respective projects during the fiscal year.

The geologic and topographic work done by the Survey for the Navy Department in Naval Petroleum Reserve No. 4 commenced with the dispatch of three parties to northern Alaska as early as possible in 1923. On the completion of the field work the scientific and technical personnel returned to Washington and spent the winter and spring in compiling their maps and reports. This report 
has been printed and is now available for distribution. While the parties that worked in 1923 were still engaged in this office work two other parties, in charge of Philip S. Smith, with J. B. Mertie, jr., geologist, and Gerald FitzGerald and R. K. Lynt, topographers, left Washington in January, 1924, and carried on surveys from the areas hitherto mapped in the Koyukuk Basin into the unmapped region in the southern and eastern parts of the reserve. These parties completed their field work at Barrow late in August and returned to Washington to prepare their maps and reports.

During the open season of $1924 \mathrm{~W}$. T. Foran, geologist, and O. L. Wix, topographer, went by sea to Wainwright and thence surveyed a strip of country in the western and southern parts of the reserve and tied with earlier surveys of Noatak River, returning to Washington at the end of the field work. On completion of Mr. Foran's work he left the Survey to accept employment with an oil company in South America, and Mr. Wix returned to the topographic branch.

In February, 1925, another party in charge of Gerald FitzGerald, topographer, with W. R. Smith as geologist, left Washington to carry on further surveys in the southern part of the reserve. This party has been entirely out of reach of mail or even telegraph since early in April, so that the precise areas covered during this fiscal year can not be learned until they return in the fall. It is expected, however, that they will have covered much of the mountain region lying between Noatak River and the streams flowing northward into the Arctic Ocean from a point near the Kugururok to the Aniuk. It is planned that they will return to Washington in October and will then complete their maps and reports.

\section{FUTURE WORK}

Although the Survey's work in Alaska has been largely instrumental in furnishing a basis on which not only the mineral industry but also other industries might proceed with assurance as to soundness of the information furnished, it has covered only a little more than a third of the Territory with maps and reports that are at least of exploratory standard. There remains over 350,000 square miles that ultimately should be surveyed, but of this area about onehalf is of such character that its survey in the near future does not seem warranted if weighed against the probability of finding profitable mineral deposits in it. However, there are areas aggregating nearly 200,000 square miles of now unmapped territory that should be surveyed as soon as funds and personnel are available. Among these areas southeastern Alaska is probably the most important and should receive early attention. In addition to containing metallic and nonmetallic minerals of commercial value, it also contains 
enormous water-power resources that will be of great value in the development of the mineral industry and in the utilization of the forest products. Next in order of importance is the completion of surveys in the broad arc of the Alaska Range and contiguous territory. This work would not only bear directly on the search for mineral deposits but also, because much of the area is in the general vicinity of the Alaska Railroad, it should indirectly contribute to the success of that Government enterprise. In northern Alaska the mountain and highland belt, which is from 100 to 300 miles wide and which stretches from the international boundary to the Arctic Ocean on the west, a distance of 500 miles, though it has only here and there been surveyed, shows indications that give foundation for the belief that valuable mineral deposits occur in it and that assistance in finding these deposits can be afforded by a thorough understanding of the geology of the region.

In addition to the distinctly areal surveys, there is also need for comprehensive studies and reports on the various larger problems relating to the different mineral resources, such as gold and copper. Already reports on the tin, coal, oil, and antimony deposits of Alaska have been published, and similar reports should be undertaken for many of the other metallic and nonmetallic minerals. The accumulation of data regarding much of the Territory has now reached a stage where the compilation of a general geologic map of the Territory is warranted. A start has been made in the correlation and compilation of all the available geologic information relating to the country adjacent to the Alaska Railroad, and a similar compilation of the data relating to southeastern Alaska is in progress. Enterprises of this sort not only focus attention on the areas in which mineral deposits of value may be sought with some probability of success but also serve to mark out those areas where the geologic conditions indicate that there is small likelihood of certain types of deposits and thus prevent the useless waste of further time and money. 
